\title{
The Role of Canopy Structure of Terminalia catappa Linn. on Decreasing Light Penetration and Ambient Temperature as Climate Change Mitigation
}

\author{
Marjenah, Karyati, Sri Sarminah, Muhammad Syafrudin, Irwan, \\ Anjas Aswar, and Indar Ruardianto
}

\begin{abstract}
Tropical almond (Terminalia catappa Linn.) is a tree that usually grows on the seashore which has a shady canopy. This tree is usually planted as an ornamental plant or a shade plant on the side of the road. The presence of the Terminalia catappa tree can provide coolness if the tree is planted in the garden or in the yard or along the roadside. This research was carried out in East Kalimantan which the sampling location were Balikpapan, Samarinda and Tenggarong City. Twenty-five trees of tropical almond were set in each city which were used as the tested samples trees. Data taken includes a) data on physical environmental characteristics (light intensity, ambient temperature and humidity) which performed under the canopy and outside canopy on each tree sample, and b) data on morphological characteristics (location, height, diameter at breast height, and shape / width of crown). The result showed that there was relationship between the volume of the tropical almond tree canopy on light penetration under and outside canopy of the tropical almond tree which indicated that there was an effect of the volume of the tropical almond tree canopy on light penetration. The light penetration will decrease along with the increase of canopy volume. There were relationships among light penetration and ambient temperature as well as relative humidity under and outside canopy of the tropical almond tree which indicated that there were the effect of light penetration on a decrease in ambient temperature and increase in relative humidity. The tropical almond tree can be used as a roadside shade tree as well as an ornamental plants in gardens or in the yard, because it can lower the ambient temperature and provide coolness.
\end{abstract}

Keywords: Shade tree, Tropical almond, translucence, ambient temperature, reduce disaster risk.

\section{Introduction}

Terminalia catappa Linn. (Tropical almond) is the name of a kind of shade tree that usually grows by the beach (Thomson and Evans 2006). Rapid growth, forming a beautiful tiers of storied, so Tropical almond often used as shade trees in the parks and roadside. Tropical almond is a deciduous trees. In East Kalimantan, Tropical almond shedding out its leaves twice a year, the first is on January to March and the second is on July to September. The grow of new shoots (vegetative) is usually followed by the emergence of generative shoots. Tropical almond leaves before shedding change its color first; from green, yelloworange, then brown-red to purple and then fall. At the time Tropical almond leaves orange, red-purple will give the beauty as it was autumn (Marjenah and Putri 2017a). In India, Raju et al. (2012) recorded information that $T$. catappa changes foliage twice in a year, the first during February-March and the second during June-August, each time with the shedding leaves and a new foliage puts forth.

$T$. catappa, widely called Indian almond or Tropical almond, has a number of other local names where English is spoken: Barbados almond, Bastard almond, Bengal almond, Country almond, Demarara almond, False kamani, Fijian almond, Malabar almond, Malay almond, Sea almond, Singapore almond, Story tree, Tavola nut, and West Indian almond. It is known as alconorque in Nicoya, Costa Rica; almendrillo, almendro, almendro de la India, or almendron (generally in Spanish-speaking areas); almendro del pais (in El Salvador); amandelboom (Surinam); amandier de Cayenne (French Guiana); amandier des indies (Haiti); amandier des tropiques (Gabon); amendoeira (Brazil); badam (India); badamier (southeast Asia and West Africa); castafia (Peru); castafiola, chapeu de sol, and guarda-sol (Brazil); kalumpit (Philippines); kamani-haole (Hawaii); ketapang (Malaysia); kotamba (Colombia); parasol (Brazil); saori (Solomon Islands); talie (Samoa); talisai (Philippines); tavola (Fiji); tipapop and tipop (Ponape, Caroline Islands); tivi (Fiji); white bombway (Andaman Islands); wilde amandel (Netherlands Antilles); zanmande (Haiti). There are many other names in the dialects of the Far East (Morton 1985).

$T$. catappa is also usually planted in various places because it provides shade and the leaves can filter out a lot of sunlight. There are several sidewalk garden areas that are suitable for tropical almond trees, such as school sidewalks, office buildings because they usually have a large enough space. The benefits of planting tropical almond trees in the school garden or office area will have an impact on the environment that feels more shady, because the amount of sunlight is filtered by the leaves and twigs, thus allowing the area to be cool and increase concentration power.

Presenting $T$. catappa tree in the yard can make it fresher and cooler because it can block the hot sun in the 
yard. This $T$. catappa tree can grow to tens of meters and a branch span of up to 4 meters or more. A wide stretch of branches / twigs will cause shade under the $T$. catappa tree, in addition to reducing the intensity of light reaching the ground, this can also lower the air temperature.

Structure of the canopy of trees can be understood as the appearance of whole branches, twigs, and leaves. The density of the tree canopy relates to the optimal intensity of sunlight, which is divided into three criteria: mild (rare), medium and heavy. This criterion is based on the high intensity of the sun that is able to penetrate the underlying strata of plants (Sutisna 2001 in Rotinsulu and Susilowaty 2014).

Light is considered the most limiting resource for trees in tropical rainforest biomes, with light penetration in the vertical dimension of rainforests declining markedly with increasing canopy depth (Weerasinghe et al. 2014). As a result, within a closed canopy, the availability of light can be reduced by up to 50-fold from the top of canopy compared with foliage in the shaded understory (Baldocchi et al. 2002).

Mitigation is an effort to reduce the greenhouse effect so that it can slow down the rate of global warming. The United Nations defines climate change mitigation as human intervention in reducing sources of greenhouse gas (GHG) emissions, especially those related to human production and consumption activities. Climate change mitigation is an effort to control climate change through activities that can reduce emissions or allow the absorption of greenhouse gases from various emission sources (Perpres RI No 46/2008).

Climate and its elements are important things to be considered and studied as well as possible, because their influence often creates big problems for humans, as well as other living things. This problem is a challenge for humans where he must try to overcome it by avoiding or minimizing the effects that do not benefit human life.

Climate tends to change by human activities such as urbanization, industrialization, deforestation, and by natural activities such as continental shifts, volcanic eruptions, change in earth's orbit to the sun, sun stains, and El Nino event. Environmental development needs to pay attention to efforts to maintain natural systems and need to analyze the impact of development on the climate.

The ambient temperature in the forest is greatly influenced by the intensity of sunlight entering the soil surface. If the canopy is getting thicker, the temperature in the forest will decrease, if the canopy is not too dense, the intensity of the incoming sunlight will increase and the ambient temperature at the ground surface will also increase (Utomo 2006).

The purpose of the research was to find out the ability of tropical almond canopy in lowering light penetration and ambient temperature; relationship of canopy volume to light intensity, light penetration and ambient temperature as well as relative humidity.

\section{Material and Methods}

\section{Study Area}

Seventy-five trees of $T$. catappa were randomly selected from three locations in East Kalimantan Province, namely Balikpapan, Samarinda, and Tenggarong City. T. catappa trees are selected as research objects that grow solitary planted on the roadside as shade plants. The research was conducted in January-October 2019.

\section{Collection and Preparation of Samples}

The sampling stages are as follows: (i) Measuring $T$. catappa tree and selecting the tree which has minimum diameter of $10 \mathrm{~cm}$ at a height of $1.3 \mathrm{~m}$ from the ground as a sample; (ii) Measuring the width of the crown/canopy (Figure 1) which covers projections according to each of the four main points to the compass (North, South, East, and West).

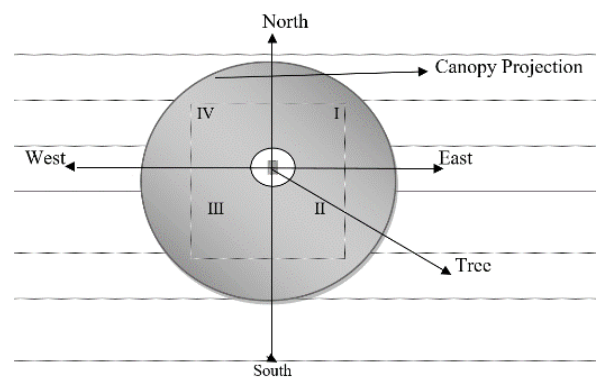

Figure 1. Projection of Canopy and Quadrant for Extending the Canopy Area (Marjenah and Putri 2017b)

\section{Physical Environmental Characteristics}

Observations or measurements of ambient temperature and humidity in the field, under canopy and open area were done once in each sample tree by using thermo-hygrometer. Measurement of light intensity is performed on every tree sample using light meter. Measurement of climate elements was repeated three times.

\section{Data Analysis}

Data analysed were using regression analysis to determine the relationship between the independent variable and the dependent variable.

\section{Result and Discussion}

The canopy thickness of Tropical almond is predicted to reduce the intensity of light that penetrates the canopy, furthermore canopy thickness can reduce ambient temperature. The presence of Tropical almond planted on the roadside as ornamental plants can reduce the temperature of the urban environment. In simple terms, it can be stated that the role of the canopy of the Tropical the 
roadside as ornamental plants can reduce the temperature of the urban environment. In simple terms, it can be stated that the role of the canopy of the Tropical almond in mitigating climate change is to reduce the temperature.
Relationship of canopy structure and climate elements (light Intensity, air temperature, and air humidity) is shown in the Figure 2, 3, and 4.

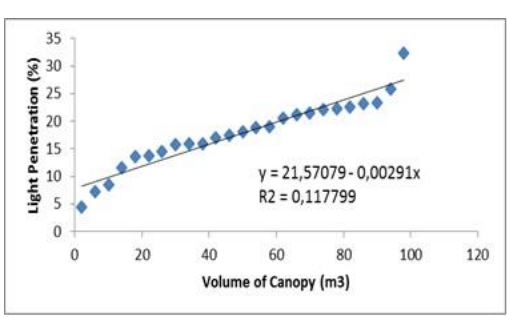

(a) Balikpapan

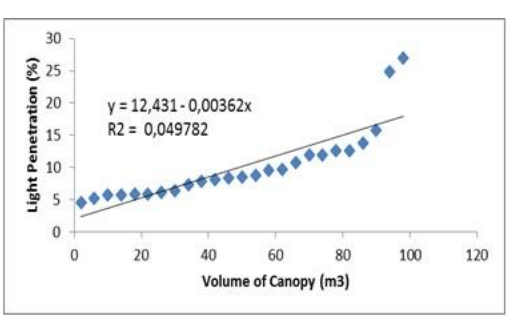

(b) Samarinda

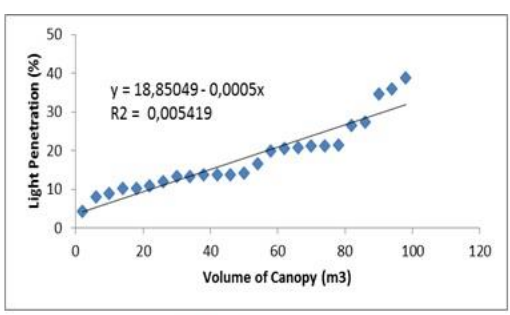

(c) Tenggarong

Figure 2. Relationship Between Canopy Structure and Light Penetration in the Cities of Balikpapan, Samarinda and Tenggarong

\section{Canopy Structure and Light Intensity}

The results show that there was relationship between the volume of the tropical almond tree canopy on light penetration under and outside of canopy of the tropical almond tree which indicated that there was an effect of the volume of the tropical almond tree canopy on light penetration. Figure 2 show several linear regressions that tend to decrease. The constant value (b) appears to have decreased in the cities of Balikpapan, Samarinda and Tenggarong. This indicated that there was a negative relationship. If there is an increase in the volume of the canopy, there will be a decrease in light penetration. $R$ square amounting $0.1178 ; 0.0498$ and 0.0054 for the cities of Balikpapan, Samarinda and Tenggarong, respectively, this indicates a very weak relationship between canopy volume and light penetration. 11.78\%; $4.98 \%$ and $0.54 \%$ light penetration is affected by the volume of the canopy. The rest is influenced by other factors.

Light is considered the most limiting resource for trees in tropical rainforest biomes, with light penetration in the vertical dimension of rainforests declining markedly with increasing canopy depth. As a result, within a closed canopy, the availability of light can be reduced by up 50 fold from the top of canopy compared with foliage in the shaded understory (Baldocchi et al. 2002). In terms of usage and space requirements grow, the width of the canopy has an important role. Canopy width can be used to predict light intensity that is exposed to trees and which is obstructed and intercepted in the canopy of a stand (Fu et al. 2013).

Light penetration into the canopy is affected by the volume of the canopy. The thicker of the canopy, more and more difficult it is for the light to penetrate. The thickness of the crown is influenced by the density of the leaves and the size of the leaves. Tropical almond leaves are generally large and absorb more light. In addition, the penetration of light into the canopy is also influenced by the direction of the light and the angle of the leaves. Leaf area is the morphological characteristics commonly used to determine the development of the canopy. Leaf canopy structure, especially of leaf angle, is relative to vertical line. Plants with horizontal leaves proceed $30-40 \%$ of the light coming through each unit of index of leaf area, while the upright leaves can proceed $45-65 \%$ of the light. With leaves that are perpendicular to sunlight on bright sunlight, the growth rate of the crop will be theoretically enhanced by the spreading of the more evenly distributed light in the canopy with upright leaves (Goldsworthy and Fisher 1992).

The influence of plant canopy on microclimate is directly and indirectly related to the attendent of canopy and stem. Branches and leaves reflect and absorb some of the sun's radiation during the day, allowing less energy to reach the ground under the canopy (Arx et al. 2012).

Light is considered the most limiting resource for trees in tropical rainforest biomes, with light penetration in the vertical dimension of rainforests declining markedly with increasing canopy depth. As a result, within a closed canopy, the availability of light can be reduced by up 50 fold from the top of canopy compared with foliage in the shaded understory (Baldocchi et al. 2002). In terms of usage and space requirements grow, the width of the canopy has an important role. Canopy width can be used to predict light intensity that is exposed to trees and which is obstructed and intercepted in the canopy of a stand (Fu et al. 2013).

Light penetration into the canopy to the ground (forest floor) affects the ambient temperature and humidity conditions. The light that penetrates the canopy affects the temperature. when the light penetration is high, the air temperature will be high as well. Meanwhile, temperature affects the humidity of the air, when the temperature is 
high the humidity will be low. Air humidity is inversely proportional to temperature.

Spatial and temporal variations in canopy structure and function affect the microclimate of the canopy, and consequently, affect temperature and humidity in various ways. For example, interactions between structural and functional properties of forests alter turbulence within and over the canopy, light penetration, heat load on leaves and soil, and physiological resistance to water and air.

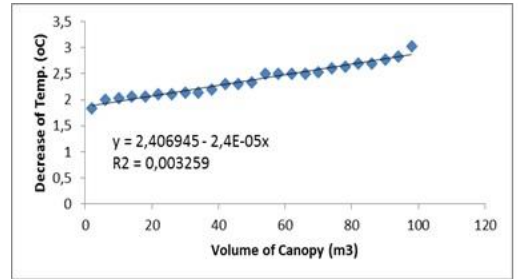

(a) Balikpapan

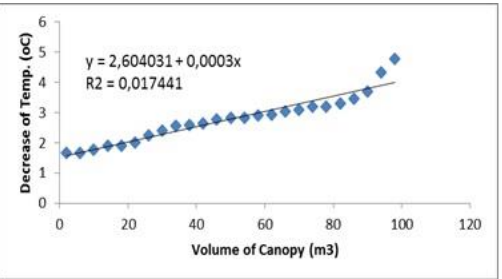

(b) Samarinda

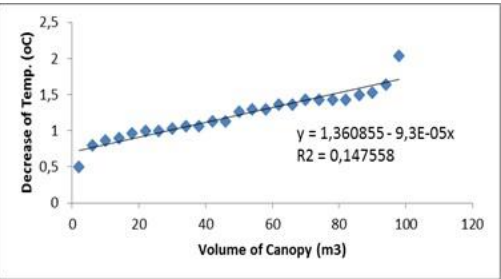

(c) Tenggarong

Figure 3. Relationship Between Canopy Structure and Decreased of Ambient Temperature in the Cities of Balikpapan, Samarinda and Tenggarong

\section{Canopy Structure and Air Temperature}

The temperature difference that occurs between the outside and under canopy is not only caused by the canopy structure which causes less light penetration from the top of the canopy to the bottom of the canopy, more than that it is also caused by the transpiration of leaves from the tree crown which causes coolness in the canopy and under the canopy.The decrease in ambient temperature is the difference between the temperature under canopy and outside canopy. Light penetration into the canopy has an effect on the light intensity reaching the ground which in turn will also affect the temperature below the canopy.

The results of the study stated that linear regression of the relationship between canopy structure and decreased ambient temperature of tropical almond tree and outside canopy indicated that there was an effect of light penetration of the tropical almond canopy on a decrease in ambient temperature. Figure 3 shows a linear regression that tends to increase. The value of the constant (b) appears to have increased in the cities of Balikpapan, Samarinda and Tenggarong. The thickness of the canopy will obstruct light penetration and will further lower the ambient temperature.

R square $0.0033 ; 0.0174$ and 0.1476 for the cities of Balikpapan, Samarinda and Tenggarong, respectively, this indicates a very weak relationship between light penetration and decreased of ambient temperature. $0.33 \% ; 1.74 \%$ and $14.76 \%$ decrease in ambient temperature in those cities are affected by light penetration in the canopy. The rest is influenced by other factors.

The air temperature on the earth's surface is relative, depending on the factors that influence it, such as the length of the sun's exposure, the tilt of the sun, cloud conditions, and the condition of the earth's surface. Air temperature varies with place and from time to time on the earth's surface. According to the place the air temperature varies vertically and horizontally and according to time from hour to hour in the day, and according to the month of the year (Satwiko 2009).

\section{Canopy Structure and Relative Humidity}

The relative humidity under the canopy is influenced by the air temperature. Humidity and temperature are two related parameters, when the air temperature is low, the relative humidity tends to be high and vice versa. If the air temperature is higher, the relative humidity will be lower. Vice versa, the lower the air temperature, the air humidity will be higher.

The results of the study stated that linear regression indicated that there was an effect of canopy structure of the tropical almond canopy on an increase in relative humidity. Figure 4 shows a linear regression that tends to increase. The value of the constant (b) appears to have increased in the cities of Balikpapan, Samarinda and Tenggarong. This indicates that there is a positive relationship.

R square $0.00865 ; 0.0217$ and 0.0547 for the cities of Balikpapan, Samarinda and Tenggarong, respectively, this indicates a very weak relationship between light penetration and humidity. $0.865 \% ; 2.17 \%$ and $5.47 \%$ humidity are affected by canopy structure. The rest is influenced by other factors.

High light environments, particularly those with other stresses such as drought and high temperatures, impose very different demands on canopy structure than those imposed in the understory. Under full sunlight conditions, there is strong evidence for the fundamental role that canopy structure plays as the first line of defense against temperature extremes and photoinhibition through 
avoidance of excessive radiation loads on the leaf surfaces (Pearcy et al. 2005).

Canopy layer is determined by the balance between the biochemically and physiologically limited demand of leaves and the diffusion-limited supply from the atmosphere and through the leaf boundary layer (Sinoquet, et al. 2001). The quantity of the light in natural environments can vary over several orders of magnitude and on a time scale that ranges from seconds to seasons. Because light is such an important environmental parameter, plants have evolved numerous biochemical and developmental responses to light that help to optimize photosynthesis and growth (Muller et al. 2001). The realism of which a canopy and its pattern of growth can be reconstructed is quite remarkable.

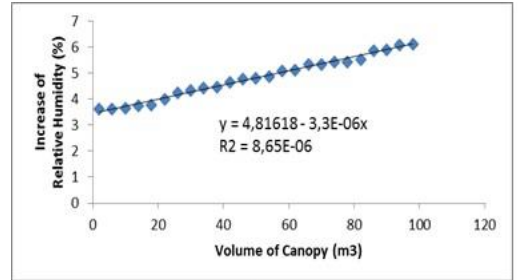

(a) Balikpapan

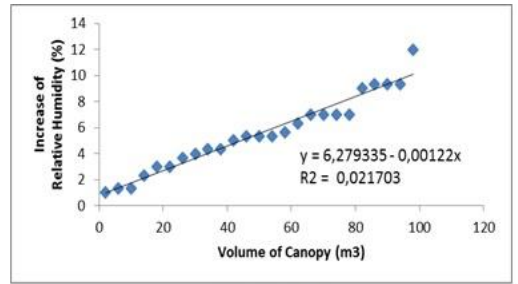

(b) Samarinda

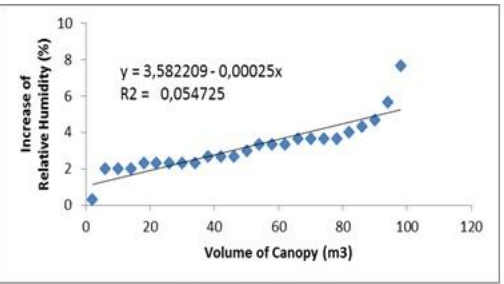

(c) Tenggarong

Figure 4. Relationship Between Canopy Structure and Increased of Relative Humidity in the Cities of Balikpapan, Samarinda and Tenggarong

Although there is no inherent limitation to doing so, developmental-rule-based models have not been used much to evaluate the functional role canopy structure on the physiological or ecological performance of plants (Pearcy et al. 2005). At the canopy scale, biophysical models vary in the way they represent canopy structure and function. Increased accuracy achieved by using multiple source abstractions, a concept that explains the different environment and sunlight as well as shaded leaves.

\section{Conclusions}

Light penetration by canopy tropical almonds can lower the ambient temperature. The lower ambient temperature will cause the relative humidity to increase. then it will make the area around the tropical almond tree cooler.

\section{Acknowledgements}

We would like to express our gratitude to Riyayatsyah, Ibnu Suyuti, Rizky Dirga, and Muhammad Said, for their assistance in the field. Many thanks to the members of Silviculture Laboratory, Faculty of Forestry, Mulawarman University, Samarinda, Indonesia for supporting this project.

\section{References}

Arx GV, Dobbertin M, Rebetez M. 2012. Spatio-temporal effects of forest canopy on understory microclimate in along-term experiment in Switzerland. Agric For Meteor 166-167 (2012): 144-155.
Baldocchi, D.D. , K.B. Wilson., and L.H. Gu. 2002. How The Environment, Canopy Structure And Canopy Physiological Functioning Influence Carbon, Water And Energy Fluxes of A Temperate Broad-Leaved Deciduous Forest-An Assessment With The Biophysical Model CANOAK. Tree Physiology 22, 1065-1077. Heron Publishing-Victoria, Canada

Fu, L., H Sun, R.P Sharma, Y Lei, H Zhang, and S Tan. 2013. Nonlinear Mixed- effects Crown Width Models for individual trees of Chinese fir (Cunninghamia lanceolata) in South-Central China. Forest Ecology and Management. 302: 210-220.

Goldsworthy PR, Fisher NM. 1992. The Physiology of Tropical Field Crops. (In Bahasa Indonesia. Translator: Tohari). Gadjah Mada University Press. Yogyakarta.

Marjenah and N.P. Putri. 2017a. Morphological Characteristic and Physical Environment of Terminalia catappa in East Kalimantan, Indonesia. Asia Journal of Forestry. Volume 1, Number 1, June 2017. Pages: 33-39.

DOI: 10.13057/asianjfor/r010105

Marjenah and N.P. Putri. 2017b. Pengaruh Elevasi Terhadap Produksi Buah Ketapang (Terminalia catappa Linn.) Sebagai Bahan Baku Pembuatan Biodiesel. Jurnal HutanTropis. 5(3): 244-251.

Morton, J.F. 1985. Indian Almond (Terminalia catappa), Salt-tolerant, Useful, Tropical Tree with "Nut" Worthy of Improvement. Economic Botany, 39(2). Pp. 101112. The New York Botanical Garden.

Muller, P., X. P. Li., and K. K. Niyogi. 2001. NonPhotochemical. A Response to Excess Light Energy. Department of Plant and Microbial Biology, University 
of California, Berkeley, California 94720-3102. Plant Physiology Vol. 125, 2001.

Pearcy, R. W. , H. Muraoka., and F. Valladares. 2005. Crown Architecture In Sun And Shade Environments: Assessing Function And Trade-Offs With A ThreeDimensional Simulation Model. New Phytologist (2005) 166: 791-800.

Perpres RI No 46/2008 Tentang Dewan Nasional Perubahan Iklim.

Raju AJS, Lakshmi PV, Ramana KV. 2012. Reproductive ecology of Terminalia pallida Brandis (Combretaceae), an endemic and medicinal tree species of India. Curr Sci 102 (6): -

Rotinsulu, J.M. and Susilowaty. 2014. Pengaruh Bentuk Tajuk Pohon Terhadap Faktor Lingkungan dan Pertumbuhan Rotan pada Sistem Agroforestri. Prosiding Seminar Nasional Silvikultur Ke IV. 250-262.

Satwiko, P. 2009. Fisika Bangunan. Yogyakarta: Penerbit Andi

Sinoquet, H., L.X Roux, B. Adam, T. Ameglio, F.A. Daudet. 2001. RATP: a model for simulating the spatial distribution of radiation absorption, transpiration and photosynthesis within canopies: application to an isolated tree crown. Plant, Cell and Environment (2001) 24, 395-406.
Thomson LAJ, and Evans B. 2006. Terminalia catappa. Species Profiles for Pacific Island Agroforestry. www.traditionaltree.org.

Utomo, B. 2006. Hutan Sebagai Masyarakat Tumbuhan Hubungannya dengan Lingkungan. Library.usu.ac.id.

Weerasinghe, L. K., D. Creek., K. Y. Crous, S. Xiang, M. J. Liddell, Matthew H. Turnbull and O. K. Atkin. 2014. Canopy Position Affects The Relationships Between Leaf Respiration And Associated Traits In A Tropical Rainforest In Far North Queensland. Tree Physiology Online at http://www.treephys.oxfordjournals.org Published by Oxford University Press. Tree Physiology Volume 34, 2014.

Marjenah, Karyati, Sri Sarminah, Muhammad Syafrudin, Irwan, Anjas Aswar, and Indar Ruardianto Silviculture Laboratory, Faculty of Forestry, University of Mulawarman Kampus Gunung Kelua. Jl. Penajam P.O. Box 1013 Samarinda 75116, East Kalimantan, Indonesia.

Tel. : : +62-541-735 089, 749068 ;

Fax. : : +62-541-735 379

E-mail : marjenah-umar@yahoo.com 